\title{
The Impact of Mineral Nitrogen Fertilization on the Occurrence of Native Diazotrophic Bacteria in Kohlrabi (Brassica oleracea) Shoots and Roots
}

\author{
Lempie K. Ekandjo ${ }^{1} \&$ Silke Ruppel ${ }^{1}$ \\ ${ }^{1}$ Leibniz-Institute of Vegetable- and Ornamental Crops, Großbeeren/Erfurt e.V., Theodor-Echtermeyer Weg 1, \\ Grossbeeren, Germany \\ Correspondence: Lempie K. Ekandjo, Leibniz-Institute of Vegetable- and Ornamental Crops, Großbeeren/Erfurt \\ e.V., Theodor-Echtermeyer Weg 1, D-14979 Grossbeeren, Germany. Tel: 49-337-017-8309. Fax: \\ 49-337-015-5391. E-mail: ekandjo@igzev.de
}

\author{
Received: October 28, 2014 Accepted: November 25, 2014 Online Published: January 15, 2015 \\ doi:10.5539/jas.v7n2p1 URL: http://dx.doi.org/10.5539/jas.v7n2p1
}

\begin{abstract}
Biological Nitrogen Fixation (BNF) is a process of great importance in crop production systems, as it provides additional natural sources of mineral nitrogen. BNF is catalyzed by diazotrophs that are identified by the nif operon presence comprising the nif $\mathrm{H}$ gene that encodes for enzyme nitrogenase synthesis. Thoroughly understanding of factors that influence diazotrophic abundance is crucial for their utilization to enhance sustainability and prevent land degradation in modern agriculture. In this study the impacts of nitrogen fertilization on diazotrophic abundance in Brassica oleracea roots and leaves was investigated in greenhouse experiments by real-time qPCR. One way ANOVA was used to compare means and bivariate Pearson correlation tested for relationships between variables. Increased nitrogen fertilization significantly increased the nitrogen content in leaves but not in roots. No significant changes in nif $\mathrm{H}$ gene copy numbers nor in proportion of nif $\mathrm{H}$ gene copy numbers were detectable. This indicates no effect of mineral $\mathrm{N}$ fertilization on the abundance of total native diazotrophic bacterial numbers in Brassica oleracea plants.
\end{abstract}

Keywords: diazotrophs, $\mathrm{NH}_{4} \mathrm{NO}_{3}$ fertilization, nitrogen fixation, nif $\mathrm{H}$ gene

\section{Introduction}

Biological nitrogen fixation (BNF) is a process through which the atmospheric inert gas $\mathrm{N}_{2}$ is converted to nutrient ammonia $\left(\mathrm{NH}_{3}\right)$. The process is carried out by bacteria. In both symbiotic and free-living bacteria, BNF is genetically controlled by a group of nif, anf or vnf genes (Joerger et al., 1991; Waugh et al., 1995; Coelho et al., 2007a; Sugitha \& Kumar, 2009). The nifH gene codes for dinitrogenase reductase and is part of the nif cluster that produces the nitrogenase catalytic enzyme complex and its regulatory proteins that are responsible for reducing atmospheric $\mathrm{N}_{2}$ to ammonia (Sugitha \& Kumar, 2009; Rosado et al., 1998; Poly et al., 2001). This functional gene has been a center of focus for researchers studying detection, dynamics and diversity of bacterial nitrogen fixing communities (Coelho et al., 2007b) and thus a potential indicator of microorganisms' ability to carry out BNF. The nifH gene is often used to quantify diazotrophs using real-time qPCR (Juraeva et al., 2006) and for their molecular identification. Among all the nitrogenase genes, nifH is the most extensively studied, with well-documented sequences from both cultured and uncultured diazotrophs (Coelho et al., 2007a; Tan et al., 2003; Deslippe \& Egger, 2006). Consequently, nifH is utilized in phylogenetic, diversity, and abundance studies of diazotrophic microorganisms (Gaby \& Buckley, 2012; Sugitha \& Kumar, 2009).

The $\mathrm{N}_{2}$ fixing enzyme nitrogenase is highly influenced by the availability of the mineral form (such as ammonium nitrate) in which nitrogen is present (Lovell, 2000; Fritzsche \& Niemann, 1990; You et al., 2005). The existence of adequate availability of mineral nitrogen in any form in the plant growth substrate and eventually in plant tissues should inhibit $\mathrm{N}_{2}$ fixation by bacteria, as the process is energetically expensive than mineral nitrogen uptake (Fritzsche \& Niemann, 1990; Hartmann, 1988). The impact of nitrogen fertilization on plant growth, photosynthetic capacities, nifH expression and isolated diazotrophs has been extensively studied (Vos \& van der Putten, 1998; Zhao et al., 2005; Cechin \& Fumiss, 2004; Pati \& Chandra, 1992), but surprisingly no study has yet focused on the quantification of diazotrophs or diazotrophs abundance dynamics in the 
phyllosphere and in rhizosphere in relation to nitrogen fertilization and the relationship between shoots and roots. More knowledge is still needed on the relationships between mineral nitrogen availability, $\mathrm{N}_{2}$ fixing activity, and the colonization and abundance of diazotrophic organisms around the plant. In order to characterize the interconnections between plant mineral $\mathrm{N}$ availability and native diazotrophs abundance we quantified diazotrophs (nifH-gene real-time qPCR) in leaves and roots of a vegetable plant kohlrabi (Brassica oleracea) grown at increasing nitrogen fertilization. Brassica oleracea is one of the non-leguminous traditional German vegetable of the cabbage family, with edible tuber and leaves and it can be eaten raw or cooked. Kohlrabi have high content of amino acids and glucosinolates which of nutritional importance to humans (Coi et al., 2010). We hypothesized that rising nitrogen content within the plant tissues by $\mathrm{NH}_{4} \mathrm{NO}_{3}$ fertilization should negatively affect the abundance of diazotrophic bacteria in both roots and leaves. This was based on the assumption that provision of plant species' optimum or above-optimum mineral nitrogen nutrients decreases the need to get additional mineral nitrogen via BNF and thereafter down-regulate the growth and settlement of diazotrophic bacteria around and within plant tissues.

\section{Materials and Methods}

\subsection{Greenhouse Experiment and Harvesting}

The study was conducted and repeated at the Leibniz-Institute of Vegetable and Ornamental Crops in Großbeeren (Brandenburg, Germany). Kohlrabi (Brassica oleracea) plants were grown at 5 different nitrogen fertilization levels including a negative control. Each nitrogen level consisted of 24 plants. All were grown for 8 weeks in the greenhouse in pots $(33 \mathrm{~cm}$ diameter) containing $1 \mathrm{~kg}$ of non-sterilized quartz sand $(0.5-1 \mathrm{~mm}$ particle size). Three times a week essential nutrients were provided as $100 \mathrm{ml}$ half strength nitrogen-free Hoagland solution (Hoagland \& Arnon, 1950). Plants were provided with reverse-osmosis purified water according to demand (about $150 \mathrm{ml}$ per day); the water that leaked through the plant pots was collected in plates

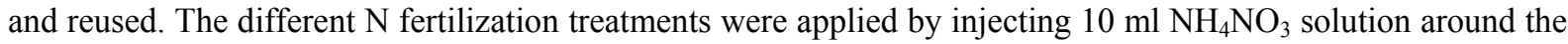
root zone with a pipette once a week. The total nitrogen administered per plant was applied during the growth period and administered at weekly intervals to prevent any negative impact of high salinity due to high nitrogen ion concentrations. The $\mathrm{N}$ levels applied as total amount of $\mathrm{NH}_{4} \mathrm{NO}_{3}$ per plant for the entire experiment were: $0 \mathrm{~g}$ for $\mathrm{N}$ level 0 (N0 negative control), $0.5 \mathrm{~g}$ for $\mathrm{N}$ level $1(\mathrm{~N} 1), 1 \mathrm{~g}$ for $\mathrm{N}$ level $2(\mathrm{~N} 2) ; 1.5 \mathrm{~g}$ for N level 3 (N3) and $2 \mathrm{~g}$ for $\mathrm{N}$ level $4(\mathrm{~N} 4)$. Other essential macronutrients were provided at a uniform rate at all nitrogen levels in this experiment (Table 1). After 8 weeks plants were harvested and separate samples of shoots and roots collected (three plants pooled per replicate). For DNA extraction and molecular analyses, samples were stored at $-20{ }^{\circ} \mathrm{C}$ overnight before lyophilization. The remaining roots and leaves were dried at $60{ }^{\circ} \mathrm{C}$ for one week, weighed and milled with a high speed plant grinder (Fritsch Pulverisette; Oberstein, Germany) for nitrogen content analysis. This experiment was repeated once.

Table 1. NPK fertilization rates (grams per plant of nitrogen $(\mathrm{N})$, phosphorus $(\mathrm{P})$ and potassium $(\mathrm{K})$ )

\begin{tabular}{llll}
\hline N level & $\mathbf{N}(\mathbf{g})$ & $\mathbf{P}(\mathbf{g})$ & $\mathbf{K}(\mathbf{g})$ \\
\hline N0 & 0 & 2.8 & 5 \\
N1 & 10 & 2.8 & 5 \\
N2 & 20 & 2.8 & 5 \\
N3 & 30 & 2.8 & 5 \\
N4 & 40 & 2.8 & 5 \\
\hline
\end{tabular}

\subsection{Nucleic Acid Extraction and qPCR}

DNA was extracted from $50 \mathrm{mg}$ lyophilized plant material using DNeasy plant mini kits (Qiagen, Hilden GmbH, Germany) according to the manufacturer's instructions. Lysis of bacterial cells was ensured by adding five $5 \mathrm{~mm}$ sterile metal beads and using a Retsch MM200 mechanical disrupter (Haan, Germany) at $30 \mathrm{rpm}$ for 5 minutes. Quantitative real-time PCR (qPCR) was run using an Advanced $^{\mathrm{TM}}$ Universal SYBR ${ }^{\circledR}$ green I dye Supermix system (Bio-Rad Laboratories, Hercules, CA, USA) as an indicator of resultant PCR amplicons. Diazotroph amplification was done with nifH specific primer pair 19F (5'-GCIWTYTAY GCIAARGGIGG-3') and 388R (5'AAICCRCCRCAIACI ACRTC-3') (Juraeva et al., 2006) by the following protocol: Cycle $1,95{ }^{\circ} \mathrm{C} / 5 \mathrm{~min}$; cycle $2,94{ }^{\circ} \mathrm{C} / 30 \mathrm{sec}, 50{ }^{\circ} \mathrm{C} / 60 \mathrm{sec}, 72{ }^{\circ} \mathrm{C} 75 \mathrm{sec}$ (recording fluorescence data) 40 repeats; cycle $3,72{ }^{\circ} \mathrm{C} / 10 \mathrm{~min}$; 
cycle 4 , melt curve $55{ }^{\circ} \mathrm{C}$ increasing temperature every $10 \mathrm{sec}$ by $0.5{ }^{\circ} \mathrm{C}$ (recording fluorescence data), 85 repeats; and cycle $5,4{ }^{\circ} \mathrm{C}$ hold (Juraeva et al. 2006). Total bacterial copy numbers were quantified using the primers 519f (5'-CAGCMGCCGCGGTAANWC-3') and 907r (5'-CCGTCAATTCMTTTRAGTT-3') specific for the bacterial domain (Lane, 1991) with the PCR protocol: Cycle $1,95{ }^{\circ} \mathrm{C} / 5 \mathrm{~min}$; cycle $2,95{ }^{\circ} \mathrm{C} / 15 \mathrm{sec}$, $53{ }^{\circ} \mathrm{C} / 30 \mathrm{sec}, 72{ }^{\circ} \mathrm{C} / 42 \mathrm{sec}$ (recording fluorescence data) 40 repeats; cycle $3,72{ }^{\circ} \mathrm{C} / 10 \mathrm{~min}$; cycle 4 , melt curve $55^{\circ} \mathrm{C}$ increasing temperature every $10 \mathrm{sec}$ by $0.5{ }^{\circ} \mathrm{C}$ (recording fluorescence data), 85 repeats; and cycle $5,4{ }^{\circ} \mathrm{C}$ hold (Ruppel et al., 2006). Fluorescence was recorded at $520 \mathrm{~nm}$ after excitation at $490 \mathrm{~nm}$ with a Bio-Rad CFX96 real-time qPCR detection system (BIO-RAD, Foster City, California, United States of America). Total bacterial and nif $\mathrm{H}$ gene copy numbers were quantified according to a standard curve generated from PCR products specific for bacteria (Escherichia coli) and nifH (Kosakonia radicincitans) genes of known copy numbers. The results were $\log 10$ transformed and calculated as gene copy numbers per $\mu \mathrm{g}$ DNA.

\subsection{Nitrogen Content Analysis}

Dried root and leaf samples were milled to a fine powder with a high speed plant grinder (Fritsch Pulverisette, Oberstein, Germany) and total nitrogen content was analyzed using a CN-Vario EL analyzer (Elementar, Hanau, Germany) ( Berger et al., 2013; Chintala et al., 2013).

\subsection{Statistical Analysis}

Comparison of mean values of 8 replicates was performed using one-way ANOVA analysis and Bonferroni-test at a P-level of $\leq 5 \%\left(\mathrm{IBM}^{\circledR}\right.$ SPSS $\left.^{\circledR} 20\right)$. Statistical differences between means are indicated by uppercase letters in roots and lowercase letters in leaves. Bars indicate the standard errors. Pearson-type correlations (r) were calculated at a P-level of $\leq 5 \%$ and at $\leq 1 \%\left(\mathrm{IBM}^{\circledR} \operatorname{SPSS}^{\circledR} 20\right)$.

\section{Results}

\section{1 $\mathrm{NH}_{4} \mathrm{NO}_{3}$ Fertilization Impact on Dry Weight and Plant Nitrogen Content}

To demonstrate the $\mathrm{N}$-fertilization impact on plant growth and nitrogen content, leaves and roots were sampled and analyzed separately after a growth period of 8 weeks. For both leaves and roots, provision of nitrogen fertilization resulted in a substantially increased plant dry matter between N0-N1, however further increase in fertilization did not result in continuous increase in plant dry matter (Figure 1). That is to say, increased shoot to root growth ratio with increasing $\mathrm{N}$ fertilization could only be seen from N0 to N1. As a result, there were significant differences $(\mathrm{p}<0.05)$ in dry matter between $\mathrm{N} 0$ and fertilized $\mathrm{N}$ levels in both roots and leaves. The mean nitrogen content was significantly higher in leaves than in roots at all levels $(p<0.05)$. There was a continuous and significant increase $(\mathrm{p}<0.05)$ in leaves' mean nitrogen content with the lowest mean recorded at N0 $(0.94 \pm 0.09 \mathrm{~g}, \mathrm{n}=8)$ and the highest recorded at N4 $(7.18 \pm 0.61 \mathrm{~g}, \mathrm{n}=8)$ (Figure 2). Roots did not exhibit the same trend; the lowest mean was also recorded at N0 $(0.62 \pm 0.79 \mathrm{~g}, \mathrm{n}=8)$ but the highest mean was at N1 $(1.69 \pm 0.22 \mathrm{~g}, \mathrm{n}=8)$ and values remained essentially constant from N1 to N4 (Figure 2). However, plant root dry weight was significantly low $(\mathrm{p}<0.05)$ at N0 than at fertilized N levels.

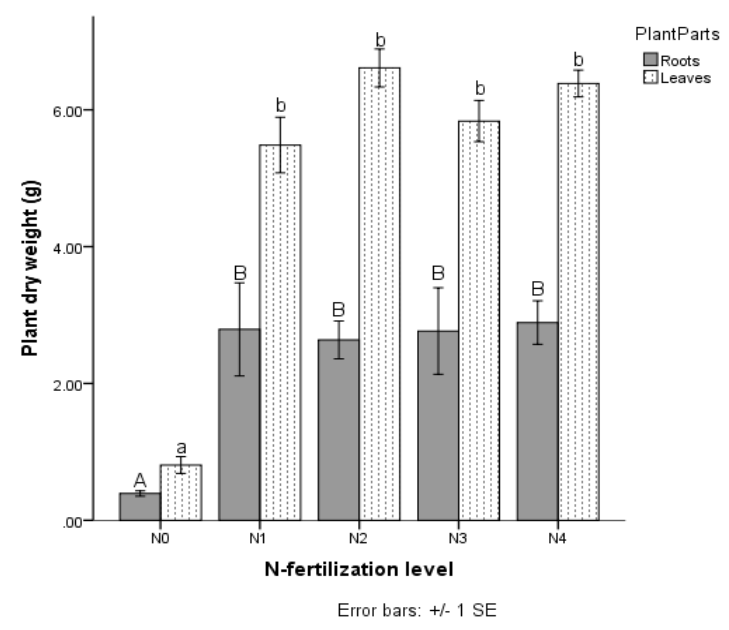

Figure 1. Dry weight $\left(g\right.$ plant $\left.{ }^{-1}\right)$ of kohlrabi leaves and roots (both $\left.n=8\right)$ at increasing levels of $\mathrm{NH}_{4} \mathrm{NO}_{3}$ fertilization. Statistical differences between means are indicated by different uppercase letters in roots and different lowercase letters in leaves 


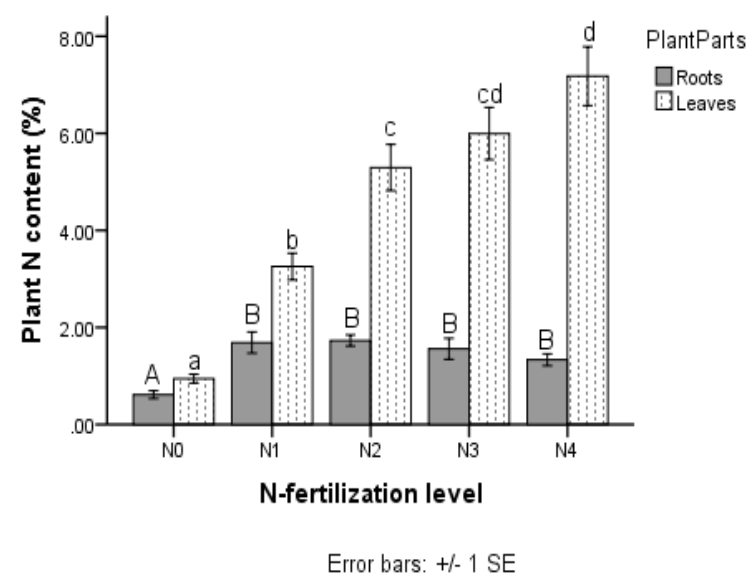

Figure 2. Plant nitrogen content (\%, dry weight basis) of kohlrabi leaves and roots (both $n=8$ ) at increasing levels of $\mathrm{NH}_{4} \mathrm{NO}_{3}$ fertilization. Statistical differences between means are indicated by different uppercase letters in roots and different lowercase letters in leaves

\subsection{Diazotrophic Bacterial (nifH) Quantification}

Quantification of total diazotrophic organisms using functional nif $\mathrm{H}$ gene copy numbers in real-time qPCR analysis revealed significantly $(\mathrm{p}<0.05)$ higher nif $\mathrm{H}$ gene copy numbers in leaves than in roots (Figure 3 ). Nonetheless, there was no detectable influence $(\mathrm{p}>0.05)$ of increased $\mathrm{N}$-fertilization on mean nif $\mathrm{H}$ gene in either roots or leaves (Figure 3). To further evaluate the N-fertilization impact on the plant microbiome community structure at each $\mathrm{N}$-fertilization level, nifH gene was calculated as a percentage of the total bacteria (16S rDNA gene copy numbers) to reveal the extent to which the total bacteria population within and around the plant was accounted for by diazotrophs. This additional calculation was done to validate the nif $\mathrm{H}$ quantity results in Figure 3. Similar to nifH copy numbers results in Figure 3 diazotrophs proportion (nif $\mathrm{H}$ gene copy numbers of total bacterial copy numbers) also did not reveal a decreasing or an increasing trend with increasing $\mathrm{N}$-fertilization on the plants (Figure 4). In addition these results also indicated a high variation in nif $\mathrm{H}$ proportion at different $\mathrm{N}$-fertilization levels. Thus there were no significant difference $(\mathrm{p}>0.05)$ in the mean nifH proportion in leaves and roots. Similar to nifH quantification, diazotrophs proportion at the total bacterial counts was higher in leaves than in roots when molecular methods were applied.

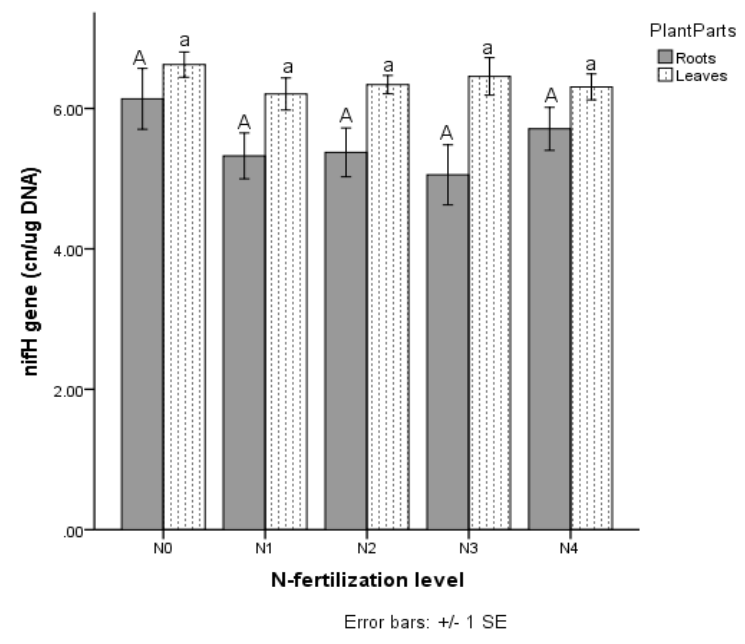

Figure 3. Total nif $\mathrm{H}$ gene copy numbers ( $\mathrm{cn})\left(n i f \mathrm{H}\right.$ gene $\left.\mathrm{cn} \mu \mathrm{g}^{-1} \mathrm{DNA}, \mathrm{n}=8\right)$ of kohlrabi leaves and roots (both $\mathrm{n}$ $=8$ ) at increasing levels of $\mathrm{NH}_{4} \mathrm{NO}_{3}$ fertilization. Statistical differences between means are indicated by different uppercase letters in roots and different lowercase letters in leaves 


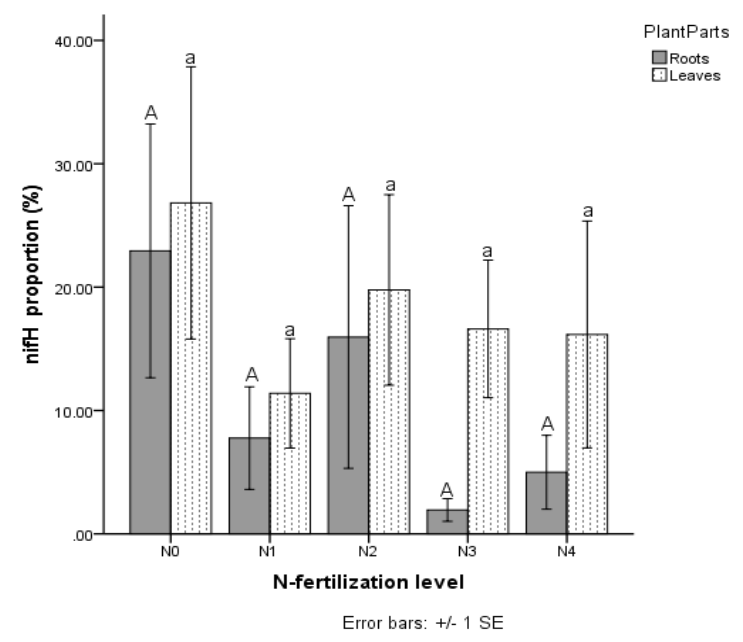

Figure 4. Proportion of nifH gene copy numbers in total bacterial copy numbers (\%) of kohlrabi leaves and roots (both $\mathrm{n}=8$ ) at different levels of $\mathrm{NH}_{4} \mathrm{NO}_{3}$ fertilization. Statistical differences between means are indicated by uppercase letters in roots and lowercase letters in leaves

\subsection{Correlation}

As expected, increasing $\mathrm{NH}_{4} \mathrm{NO}_{3}$ fertilization was significantly positively correlated to kohlrabi leaf dry matter $\left(\mathrm{r}=0.72^{* *}\right)$ and leaf nitrogen content $\left(\mathrm{r}=0.86^{* *}\right)$ (Table 2). Root dry matter also showed significant correlation to $\mathrm{NH}_{4} \mathrm{NO}_{3}$ fertilization $\left(\mathrm{r}=0.46^{* *}\right)$ while, $\mathrm{N}$-content showed no significant correlation to $\mathrm{NH}_{4} \mathrm{NO}_{3}$ fertilization $(\mathrm{r}=0.31)$. Nevertheless, increased $\mathrm{NH}_{4} \mathrm{NO}_{3}$ fertilization did not significantly impact nifH gene copy numbers in leaves $(\mathrm{r}=0.10)$ or in roots $(\mathrm{r}=-0.15)$. Likewise the nif $\mathrm{H}$ gene copy number proportion of total bacterial copy numbers was not significantly correlated to increased $\mathrm{N}$-fertilization in either leaves $(\mathrm{r}=-0.11)$ or roots $(\mathrm{r}=-0.30)$ (Table 2). Furthermore to test for interactions between leaves and roots correlation test was done for different variables. In this test only nifH quantity roots was positively correlated $(0.512 * *)$ to the $n i f \mathrm{H}$ quantity in leaves among other variables.

Table 2. The impact of $\mathrm{N}$ fertilization other studied variables

\begin{tabular}{lll}
\hline Variables & Leaves ( $r$ values) & Roots (r values) \\
\hline Dry weight & $+\left(0.72^{* *}\right)$ & $+\left(0.46^{* *}\right)$ \\
Nitrogen content & $+\left(0.86^{* *}\right)$ & $0(0.31)$ \\
nifH quantity & $0(-0.10)$ & $0(-0.15)$ \\
nifH percentage & $0(-0.11)$ & $0(-0.30)$
\end{tabular}

Keys: + Positive correlations; - Negative correlations; 0 insignificant correlations; * Correlation is significant at the 0.05 level; ** Correlation is significant at the 0.01 level.

\section{Discussion}

The unexpected insignificant differences between means and correlation coefficients found between $n i f \mathrm{H}$, nif $\mathrm{H}$ proportion in relation to $\mathrm{N}$-fertilization could be explained by the fact that most diazotrophic bacteria have multiple plant growth promoting functions in associated plants, and BNF is one of those (Yuan et al., 2012; Fernando \& Linderman, 1995; Xu et al., 2004). Other functions around the plants include phosphate transformer genes, siderophore genes as wells as phytohormone production genes and of course these functions vary between strains (Witzel et al., 2012). These other functions can contribute to a selective advantage unrelated to nitrogen fixation for plants colonized by diazotrophic bacteria. In this model, the absence of the need for the BNF does not necessarily lead to the loss of diazotrophs from the plant as they still provide other benefits to the plant. It is worth noting that presence of nif $\mathrm{H}$ gene-containing microorganisms does not invariably indicate ongoing BNF, especially when there is mineral nitrogen available to the plant (Fritzsche \& Niemann, 1990). Fritzsche and Niemann (1990) also documented a decrease in BNF activity with provision of increased $\mathrm{NH}_{4} \mathrm{Cl}$ but did not 
report the impact on the nitrogen fixing bacterial population.

The regulation of diazotrophic activities seems very complex. In this study, provision of sufficient ammonium nitrate was ensured by adding the compound above the documented optimum requirements in the literature (Carmen et al., 2007). From the Fritzsche and Niemann (1990) findings, it appears that BNF in the rhizosphere does not solely depend on total absence of mineral nitrogen sources. Similar findings recorded by Lovell (2000) indicate that there was still BNF activity in open marine water that had abundant ammonium availability. In addition some findings indicated that high level of mineral nitrogen supply might inhibit $\mathrm{N}_{2}$ fixation in some diazotrophic species but not in all (Rosado, 1998; Lovell, 2000; Ruppel \& Merbach, 1995). Lovell (2000) even reported an increase in nitrogenase expression with increase in mineral $\mathrm{N}$ availability and concluded that short term manipulation in nitrogen supply does not have significant impact on the diazotrophic communities. Similarly Juvaera et al. (2006) reported that although there were physiological changes in plants due to $\mathrm{N}$ fertilization these did not cause significant changes to nif $\mathrm{H}$ gene abundance or to the diazotrophic culturable organisms around the plants.

\section{Conclusion}

These results revealed that increased $\mathrm{NH}_{4} \mathrm{NO}_{3}$ fertilization had no significant impact on diazotrophs abundance in rhizosphere and in the rhizosphere of the studied kohlrabi plants (Brassica oleracea), despite the increased nitrogen content observed within plant tissues particularly in the phylosphere. However, these results highlight the potential importance of the phyllosphere in BNF, since diazotrophs abundance (nifH gene copy numbers) were higher in leaves than in roots. Finally there is a need for more extensive investigations in both phyllosphere and rhizosphere to determine if the nifH genes were being expressed or not in the diazotrophic communities under adequate supply of mineral nitrogen.

\section{Acknowledgements}

I am gratefully to DAAD and IGZ.e.V institutes for funding my research and to the entire plant nutrition team at IGZ for technical support.

\section{References}

Berger, B., Brock, A., \& Ruppel, S. (2013). Nitrogen supply influences plant growth and transcriptional responses induced Enterobacter radicincitans in Solanum lycopersicum. Plant and Soil, 370(2), 641-652. http://dx.doi.org/10.1007/s11104-013-1633-0

Burgmann, H., Wider, F., Sigler, W. V., \& Zeyer, J. (2003). mRNA extraction and reverse transcriptase-PCR protocol for detection of nif $\mathrm{H}$ gene expression by Azotobacter vineandii in soil. Appl. Environ. Microbiol., 69, 1928-1935. http://dx.doi.org/10.1128/AEM.69.4.1928-1935.2003

Carmen, F., Fink, M., Laber, H., Maync, A., Paschold, P., Acharpf, H., et al. (2007). Gartenbauliche Berichte (4th ed.). Großbeeren: IGZ.

Cechin, I., \& Fumis, T. F. (2004). Effect of Nitrogen supply on growth and photosynthesis of sunflower plants grown in the greenhouse. Plant Science, 166, 1379-1385. http://dx.doi.org/10.1016/j.plantsci.2004.01.020

Chintala, R., Clay, D. E., Schumacher, T. E., Malo, D. D., \& Julson, J. L. (2013). Optimization of Oxygen parameters for analyzing carbon and nitrogen in biochar materials. Analytical Letters, 46, $532-538$. http://dx.doi.org/10.1080/00032719.2012.721103

Choi, S., Ryu, D., Park, S., Ahn, K., Lim, Y., \& An, G. (2010). Composition Analysis between Kohlrabi (Brassica oleracea var. gongylodes) and Radish (Raphanus sativus). Korean Journal of Horticultural Science Technology, 28(3), 469-475.

Coelho, M. R. R., de Vos, M., Carneiro, N., Marriel, I. E., Paiva, E., \& Seldin, L. (2007a). Diversity of nifH pools in two cultivars of sorghum (Sorghum bicolor) treated with contrasting levels of nitrogen fertilizer. FEMS Microbiology Letter, 279, 15-22. http://dx.doi.org/10.1111/j.1574-6968.2007.00975.x

Coelho, M. R. R., Mota, F. F., Carneiro, N. P., Marriel, I. E., Paiva, E., Rosado, A. S., \& Seldin, L. (2007b). Diversity of Penibacillus spp. In the rhizosphere of four sorghum (Sorghum bicolor) cultivars sown with two contrasting levels of nitrogen fertilizer accessed by rpoB based PCR-DGGE and sequencing analysis. Journal of Microbiology Biotechnology, 54, 753-760.

Deslippe, J., \& Egger, K. (2006). Molecular diversity of nifH genes from bacteria associated with high artic dwarf shrubs. Microbial Ecology, 51, 516-525. http://dx.doi.org/10.1007/s00248-006-9070-8

Farnedlid, H. (2013). Distribution and activity of nitrogen-fixing bacteria in marine and estuarine waters. 
Linneaus University Dissertations: Sweden: Linnaeus University Press.

Fernando, W. G. D., \& Linderman, R. G. (1995). Inhibition of Phytophthora vignae and root rot of cowpea by soil bacteria. Biological Agricultural Horticulture, $12, \quad 1-4$. http://dx.doi.org/10.1080/01448765.1995.9754719

Fritzsche, C., \& Niemann, E. G. (1990). Nitrogen fixation in activities continuous culture with $\mathrm{NH}_{4} \mathrm{Cl}$ containing media. Applied Environmental Biology, 56, 1160-1123.

Fuentes-Ramirez, L. E., Caballero-Mellado, J., Sepulveda, J., \& Martinez-Romero, E. (1999). Colonization of sugarcane by Acetobacter diazotrophicus is inhibited by high $\mathrm{N}$ fertilization. FEMS Microbiol. Ecol., 29, 117-128. http://dx.doi.org/10.1111/j.1574-6941.1999.tb00603.x

Gaby, J. C., \& Buckley, D. H. (2012). A comprehensive evaluation of PCR primers to amplify the nifH of Nitrogenase. Plos One, 7, e42149. http://dx.doi.org/10.1371/journal.pone.0042149

Hartmann, A. (1988). Eco-physiological aspects of growth and nitrogen fixation in Azosprillum spp. Plant Soil, $110,225-238$.

Hoagland, R., \& Arnon, I. (1950). The water-culture methods for growing plants without soil. United States of America: California agricultural experiment station.

Joerger, R. D., Wolfinger, E. D., \& Bishop, P. E. (1991). The encoding dinitrogenase reductase 2 is required for expression of the second alternative nitrogenase from Azotobacter vinelandii. Journal of Bactriology, 173, 4440-4446.

Juraeva, D., George, E., Davranov, K., \& Ruppel, S. (2006). Detection and quantification of the $n i f \mathrm{H}$ gene in the shoot and root of cucumber plants. Canadian Journal of Microbiology, 52, 731-739. http://dx.doi.org/10.1139/W06-025

Lane, D. J. (1991). 16S/23S rRNA sequencing. In E. Stackebrandt \& M. Goodfellow (Eds.), Nucleic acid techniques in bacterial systematics (pp. 205-248). Chichester, England: Wiley.

Limmer, C., \& Drake, H. R. (1998). Effects of carbon, nitrogen, and electron acceptor availability in anaerobic N2-fixation in a beech forest soil. Soil Biol Biochem, 30, 153-158. http://dx.doi.org/10.1016/S0038-0717(97)00099-0

Lovell, C. R., Piceno, Y. M., Quarttro, J. M., \& Bagwell, C. E. (2000). Molecular analysis of diazotroph diversity in the rhizosphere of the smooth Cordgrass, Spartina alterniflora. Applied and Environmental Microbiology, 66(9), 3814-3822. http://dx.doi.org/10.1128/AEM.66.9.3814-3822.2000

Pati, B. R., \& Chandra, A. K. (1992). Nitrogen fixing potentialities of the phyllospheric bacteria in relation to the concentration of sucrose in the media. Zentralblatt für mikrobiologie, 147(7), 435-440.

Poly, F., Monrozier, L. J., \& Bally, R. (2001). Improvement in the RFLP procedures for studying the diversity of nif $\mathrm{H}$ genes in communities of nitrogen fixers in soil. Res. Microbiol., 152, 95-103. http://dx.doi.org/10.1016/S0923-2508(00)01172-4

Qiagen. (2006). DNeasy plant handbook. Germany, Hilden: Qiagen.

Rosado, A. S., Duarte, G. F., Seldin, L., \& Elsas, J. D. (1998). Genetic diversity of nifH gene sequences in Paenibacillus azotofixans strains and soil samples analyzed by Denaturing Gradient Gel Electrophoresis of PCR-Amplified gene fragments. Applied and Environmental Microbiology, 64(8), 2770-2779.

Ruppel, S., \& Merbach, W. (1995). Effects of different nitrogen sources on nitrogen fixation and bacterial growth of Pantoea agglomerans and Azospirillum spp. in bacterial pure culture: An investigation using ${ }^{15} \mathrm{~N}_{2}$ and acetylene incubation. Microbiol. Res., 150, 409-418. http://dx.doi.org/10.1016/S0944-5013(11)80023-6

Ruppel, S., \& Merbach, W. (1997). Effect of ammonium and nitrate on specific ${ }^{15} \mathrm{~N}_{2}$-fixation of Azospirillum spp. and Pantoae agglomerans in association with wheat plants. Microbiol. Res., 152, 377-383. http://dx.doi.org/10.1016/S0944-5013(97)80055-9

Ruppel, S., Rühlmann, J., \& Merbach, W. (2006). Quantification and localization of bacteria in plant tissues using quantitative real-time PCR and online emission fingerprinting. Plant and Soil, 286(1-2), 21-35. http://dx.doi.org/10.1007/s11104-006-9023-5

Sugitha, T. C., \& Kumar, K. (2009). Identification of nif $\mathrm{H}$ genes of heterophic and endophytic diazotrophs associated with rice (Oryza sativa L.) by targeted DNA finger printing. African Journal of Biotechnology, $8(22), 6249-6252$. 
Sutton, S. (2010). The most probable number and its use in quality control microbiology. Journal of GXP Compliance, 14(4), 28-33.

Tan, Z., Suga, Y., \& Reinhold-Hurek, B. (2003). Effect of N fertilization, plant genotype and environmental conditions on nif $\mathrm{H}$ gene pools in roots of rice. Environmental Biology, 5, 1009-1015. http://dx.doi.org/10.1046/j.1462-2920.2003.00491.x

Vos, J., \& van der Putten, P. E. L. (1998). Effects of nitrogen supply on leaf growth, leaf nitrogen economy and photosynthetic capacity in potato. Field Crops Research, 59, 63-72. http://dx.doi.org/10.1016/S0378-4290(98)00107-5

Waugh, S. I., Paulsen, D. M., Mylona, P. V., Maynard, R. H., Premakumar, R., \& Bishop, P. E. (1995). The gene encoding the delta subunits of dinitrogenase 2 and 3 are required for Mo-independent diazotrophic growth by Azotobacter vinelandii. Journal of Bacteriology, 177, 1505-1510.

Witzel, K., Gwinn-Giglio, M., Nadendla, S., Shefchek, K., \& Ruppel, R. (2012). Genome sequences of Enterobacter radicincitans DSM16656, a plant growth promoting endophyte. Journals of Bacteriology, 194(19), 5468-5471. http://dx.doi.org/10.1128/JB.01193-12

Xu, C. K., Mo, M. H., Zhang, L. M., \& Zhang, K. Q. (2004). Soil volatile fungistasis and volatile fungistatic compounds. Soil Biology Biochemistry, 36, 1997-2004. http://dx.doi.org/10.1016/j.soilbio.2004.07.020

You, M., Nishigushi, M., Saito, A., Isawa, T., Mitsui, H., et al. (2005). Expression of the nifH gene of a Herbaspirillum endophyte in wild rice species: daily rhythm during the light dark cycle. Applied and Environmental Microbiology, 71(12), 8183-8190. http://dx.doi.org/10.1128/AEM.71.12.8183-8190.2005

Yuan, J., Raza, W., Shen, Q., \& Huang, Q. (2012). Antifungal activity of Bacillus amyloliquefaciens NJN-6 volatile compounds against Fusarium oxysporum f. sp. Cubanse. Applied Environmental Microbiology, 78(16), 5942-5994. http://dx.doi.org/10.1128/AEM.01357-12

Zhao, D., Reddy, R. K., Kakani, G. V., \& Reddy, V. R. (2005). Nitrogen deficiency effects on plant growth, leaf photosynthesis, and hyperspectral reflectance properties of Sorghum. European Journal of Agronomy, 22, 391-403. http://dx.doi.org/10.1016/j.eja.2004.06.005

\section{Copyrights}

Copyright for this article is retained by the author(s), with first publication rights granted to the journal.

This is an open-access article distributed under the terms and conditions of the Creative Commons Attribution license (http://creativecommons.org/licenses/by/3.0/). 